\title{
MANUFACTURED PROTOTYPE TO SEPARATE THE SEEDS OF WATERMELON PULP
}

\author{
ABDRABO, A.F.A \\ Ag. Eng. Res. Inst. (ARC), Giza, Egypt \\ (Manuscript received 8 December 2013)
}

\begin{abstract}
Experiments were carried out to manufacturing a combine prototype from the local materials to suit separating the seeds of watermelon pulp, cleaning and collecting the seeds. The experiments were carried out to evaluate the performance of a combine prototype, as well. The performance of the manufactured prototype was studied under the following parameters: four feeding rate $(100,130,160$ and $200 \mathrm{~kg} / \mathrm{min})$, four drum speed $(6.2,8.5,10.6$ and $13.2 \mathrm{~m} / \mathrm{s})$ and four number of resting days after harvest $(2,4,6$ and 8 days) on the seed losses $\%$, seed damaged $\%$, productivity $\mathrm{kg} / \mathrm{h}$, machine efficiency\%, consumed power $\mathrm{kW}$, and operating cost L.E/fed. The experimental results reveal that the highest value of the seed losses, was $7.0 \%$ at feeding rate of $200 \mathrm{~kg} / \mathrm{min}$, drum speed of $6.2 \mathrm{~m} / \mathrm{s}$ and 2 days after harvesting. While the lowest value of the seed losses, was $1.2 \%$ at feeding rate of $100 \mathrm{~kg} / \mathrm{min}$, drum speed of $13.2 \mathrm{~m} / \mathrm{s}$ and 6 days after harvesting. The machine productivity increased by the increasing feeding rate and drum speed. The minimum operating cost of 185.0 L.E./fed., was recorded at feeding rate of $100 \mathrm{~kg} / \mathrm{min}$, drum speed of $13.2 \mathrm{~m} / \mathrm{se}$ and 6 days after harvest.
\end{abstract}

\section{INTRODUCTION}

Watermelon pulp is the important vegetable crops in Egypt, which can be exported to other countries. Spread cultivation of watermelon pulp in the recent period due to higher income, limited period of their stay in the ground. It has been widely cultivated especially in Northern Regions of Egypt, such as Kafr El-Sheikh Governorate, and newly reclaimed lands. The total cultivated area of watermelon is about 175000 fed., with an average seed yield of $500-650 \mathrm{~kg} / \mathrm{fed}$. (Ministry of Agriculture, 2012). But there is a problem in separating the seeds of watermelon pulp requires a large number of employment and the high cost of manual separation process of seeds. So the idea of this research designs and manufactures prototype from the local materials to suit separating the seeds and be a low-cost Vergano et al., (1992) designed and evaluated performance of axial-flow vegetable seed extracting machine. They compared the manual with the mechanical seed extraction for different vegetable fruits. They found that the manual seed extraction was $0.47,1.20$, $1.26,1.52,1.83,2.20$ and $3.14 \mathrm{~kg} / \mathrm{man} . \mathrm{h}$ for cucumber, watermelon, tomato, summer squash, baronial, squash melon and chilies, respectively. Meanwhile, the productivity 
of the seed extracting machine varied from 310 to $1930 \mathrm{~kg} / \mathrm{h}$ for all investigated vegetable fruits. Abou-Elmagd et al., (2002) designed and tested a crushing machine for watermelon seeds-extraction. The machine consists of hopper, crushing drum with knives, screw conveyer and water source. Abou El-Magd et al., (2006) studded the proper design and evaluation of an equipment for extracting water melon seeds.They found that increasing the feed rate from 60 to $90 \mathrm{~kg} / \mathrm{min}$., increased seed losses from 4.49 to $5.68 \%$. It was observed that increasing the feed rate tends to increase the seed losses at all variable levels. However, the seed losses increased by $26.5 \%$ as the feed rate increased from 60 to $90 \mathrm{~kg} / \mathrm{min}$. It can be stated that drum speed had considerably effect on the seed losses. Seed losses increased from $3.83 \%$ to $6.90 \%$ when the drum speed increased by 1.5 times. This trend may be because of decreasing the impact force of knives and the kinetic energy of the seeds, which make seed more, subjected to the smashing forces. Tayel et al., (2010) found that increment of spent time between harvesting and extracting process decreases seed damage. Also, they found that the feed rate of $116 \mathrm{~kg} / \mathrm{min}$., drum speed of 2.48 $\mathrm{m} / \mathrm{se}$, drum- concave clearance of $15 \mathrm{~mm}$, and 6 days time of extracting after harvesting represent the minimum values of seeds damage. Baldwin (1990) mentioned that mechanical damaged during harvest is caused largely by fast moving parts of the threshing - drum of the combine. Abd El-Hameed, (1994) found that increasing the drum speed increased separating efficiency. The maximum separating efficiency was obtained by using metal spike drum, hole concave type and drum concave clearance. Nwosu,(1988)found that the traditional method requires a lot of time and labor. Whereas, 25-30 workers are needed for one feddan .Kholiff et al.,(2005)development and evaluation of seed extracting machine for seed melons. They found that the highest values of seed losses were 13.62, 9.54 and $6.68 \%$ at drum speed of $0.35 \mathrm{~m} / \mathrm{se}$ and feeding rate of $3.71 \mathrm{mg} / \mathrm{h}$ for the drum shapes triangle , square and hexagonal respectively. The data also, showed that drum speed triangle gave the highest amount of seed losses and these may be due the reduce of separating efficiency of this drum shape. Also, they found that the drum speed increase tends to increase the seed extracting efficiency. Yehia et al., (2010) studied some physical and mechanical properties of cantaloupe Gallia verity. The main results in this study were : physical properties of cantaloupe fruits: diameter $82.12-\mathrm{n} 113.51$ $\mathrm{mm}$, height $82.07-119.95 \mathrm{~mm}$, mass $329.2-940.6 \mathrm{~g}$, volume $380-860 \mathrm{~cm}^{3}$, projected area $85.85-160.95 \mathrm{~cm}^{2}$, real density $0.69-1.08 \mathrm{~g} / \mathrm{cm}^{3}$ bulk density 0.51 $\mathrm{g} / \mathrm{cm}^{3}$, sphericity $0.88-1.07$. Mechanical properties the average of cantaloupe - fruit firmness was $62.5 \mathrm{~N} / \mathrm{cm}^{2}$, the maximum $80.4 \mathrm{~N} / \mathrm{cm}^{2}$ and the minimum $28.6 \mathrm{~N} / \mathrm{cm}^{2} \cdot \mathrm{El}$ Lithy, (2012) found that the fruit-hopper dimensions $=60 \times 60 \times 40 \mathrm{~cm} .$, convey-belt 
width=more than maximum friction angle between cantaloupe fruits and stainless steal surface $=$ more than $25^{\circ}$.and vibrated-chain belt width $=$ more than maximum diameter of cantaloupe fruits $=200 \mathrm{~mm}$. Distance between roods of chain belt=more than seed size=about $10 \mathrm{~mm}$. The objectives of this work are devoted to :

- Manufacturing and evaluating prototype to separate the seeds of watermelon pulp,

- Access to the highest separation efficiency of prototype, and reduce the total cost

\section{MATERIALS AND METHODS}

The investigation under this study was locally manufacturing a small prototype in order to suit the operations of separating the seeds of water melon pulp, cleaning and collecting the seeds per operating time.The prototype was fabricated with locally available materials at the manufacture Center of Kafr El - Sheikh. A 44.78kW (60 hp) Nasr tractor run it and the power was transmitted from the tractor to the prototype, gearbox through PTO shaft. The field experiments were carried out at Almorabin village, Kafr El - Sheikh Governorate during agricultural season of 2011 - 2012. In this experiment, watermelon Sakha 101 variety was used and the total planted area was 5 feddans.

\section{General technical specifications of prototype:}

The general specifications of the watermelon prototype are presented in Table 1 and sketched in Fig. 1.

Table 1.The technical specification of the combine prototype watermelon pulp

\begin{tabular}{|l|l|}
\hline \multicolumn{1}{|c|}{ Specification } & \\
\hline Main dimensions; & \\
\hline Total length, $\mathrm{cm}$ & 180 \\
$\quad$ Total width, $\mathrm{cm}$ & 120 \\
Total height, $\mathrm{cm}$ & 170 \\
$\quad$ Total mass, $\mathrm{kg}$ & 450 \\
Source of power & Tractor PTO \\
Length of cutting drum,cm & 150 \\
Diameter of the drum,cm & 30 \\
Length of the flipping blades,cm & 150 \\
Length of the seeds auger,cm & 155 \\
No. of cross bar & 10 \\
\hline
\end{tabular}




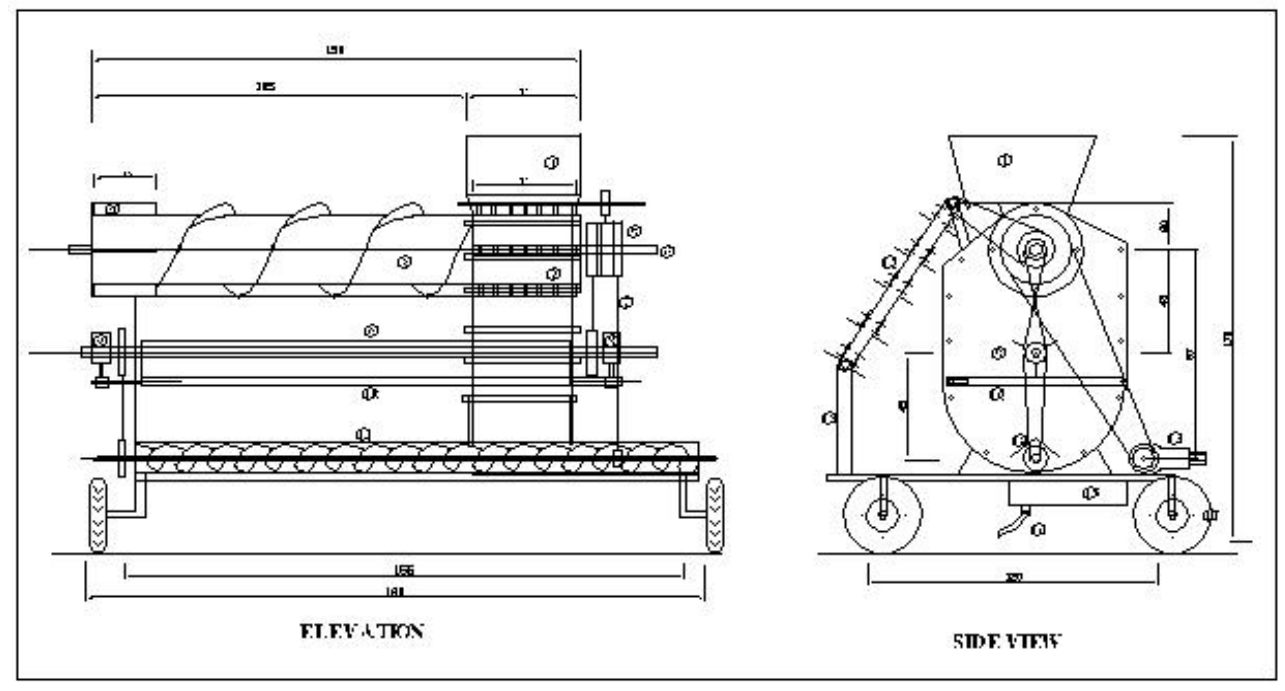
1-Feed slot
2- Spike tooth bars 3- Drum
4- Part expel waste
5- Pulley
6- Shaft 7- V-belt 8-Crank 9- Flipping blades 10-Sieve 11-Augers
12- Elevator unit $\quad 13$ - Take off shaft $\quad 14$ - Compilation of plate 15- Tank of seeds
16- Track 17-Ground wheel 18-Stand Dims. in $\mathrm{cm}$

Fig. 1. The main parts and units of the watermelon prototype.

Fig. 2. shows the threshing drum of watermelon pulp. It's a cylinder of 155.0 $\mathrm{cm}$ in length with $30.0 \mathrm{~cm}$ diameter. The drum shaft passes through the center of the cylinder drum where a circular steel sheet is welded to close each of the drum ends. The threshing section width is $45 \mathrm{~cm}$ and consists of 4 bars spike-tooth fixed on the drum surface. The other part of the drum is separating section width of $105.0 \mathrm{~cm}$ where one agitator bars and $10.0 \mathrm{~cm}$ height are fixed to the above mentioned bases spirally on the drum .The kernels separated here fall also into the front and rear conveying auger through. The Watermelon peel is discharged on the left hand side onto the ground or is delivered via conveyor belt at the rear of the prototype.

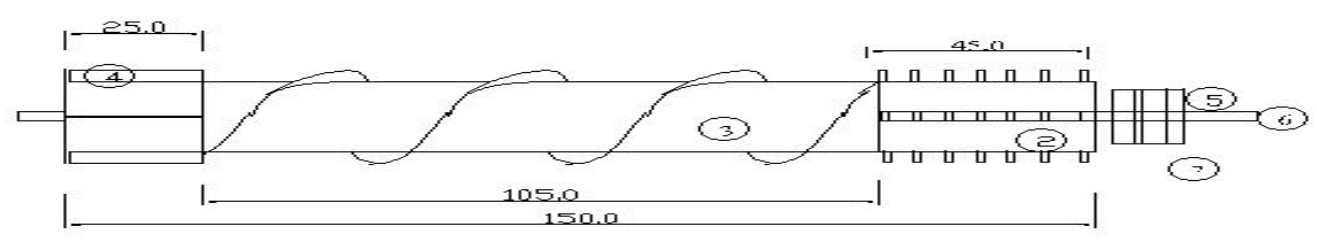

Fig. 2. Threshing drum of watermelon pulp:

Concave is a network of semi-circular surrounded below the threshing drum with a clearance of $5 \mathrm{~mm}$ and this network is a slab of a steel sheet thickness of 3 $\mathrm{mm}$ and there are slots circular diameter of $16 \mathrm{~mm}$ to allow only the mixture of seeds 
and liquid flesh material to pass through its holes to fall on the sieve separation of grain but peel the melon be expelled from the slot side end .

Fig. (3) shows the elevator unit having ten cross bars fixed on the chain. Every chain is $210 \mathrm{~cm}$ long. This belt moves through another small belt fixed on a hoop for shifting the movement. The dimension of each cross of $65 \mathrm{~cm}$ lengths, $12 \mathrm{~cm}$ width, $10 \mathrm{~cm}$ height. After removing the leaves beet, it is shifted to the collecting tank. The pulley was fixed on the driver shaft with speed of $130 \mathrm{rpm}$

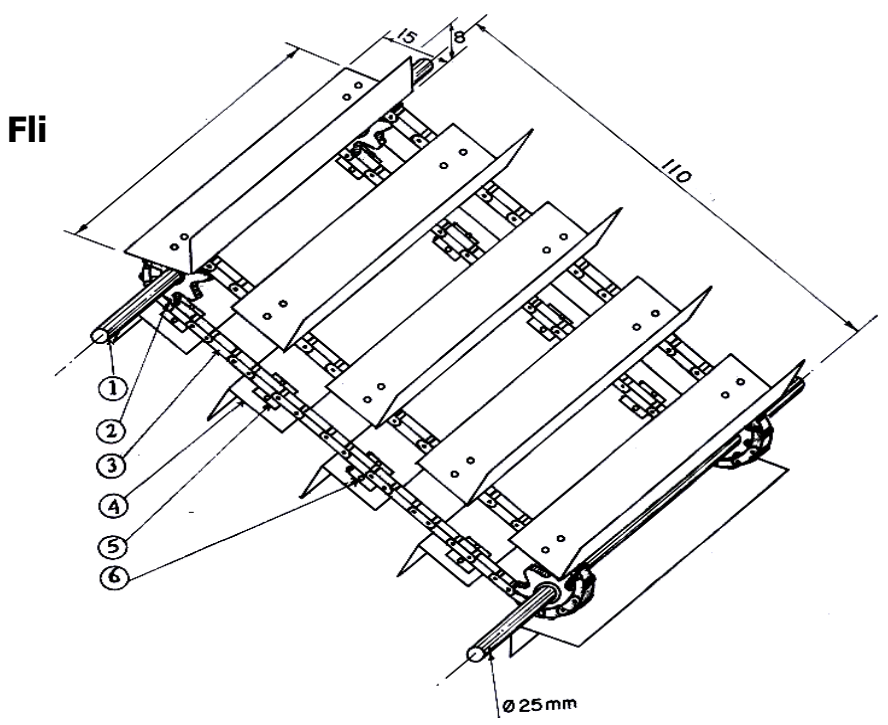

$\begin{array}{ll}\text { 1-Drive shaft } & \text { 4-Cross b.r } \\ \text { 2-Sprocket wheel } & 5 \text {-Catcher crossbar } \\ \text { 3-Track } & 6 \text {-Hex bolt }\end{array}$

DIM.IN CM

Fig.3.The Water melon elevator unit:

Fig. (4) shows the flipping blades and the expulsion of wastes. This part is made of column steel diameter $25 \mathrm{~mm}$ and length of $160 \mathrm{~cm}$ and installed three blades of sheet evenly distributed on the perimeter of column of iron and feathers thickness of $3 \mathrm{~mm}$ with length of $125 \mathrm{~cm}$ and height of $10 \mathrm{~cm}$. It's based on two chairs Part to moving in both sides. The aim of this section is flipping and falling mixture of individual network chest sieve chapter until fall of the sieve and grain waste is expelled to the outside through the open committees. 


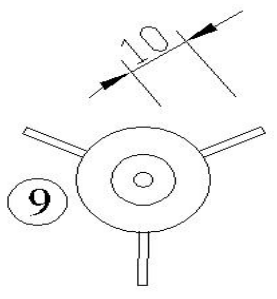

S.V.

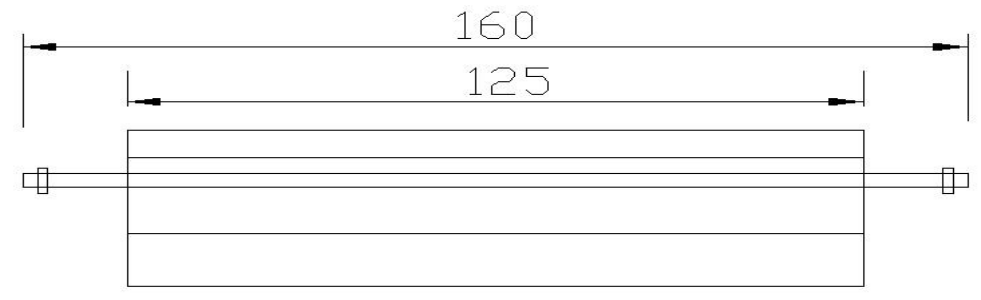

$E\llcorner E$

Fig. 4. The Flipping blades and the expulsion of wastes.

Seeds separating unit consists of iron framework in the form of a rectangle of $125 \mathrm{~cm}$ long and $65 \mathrm{~cm}$ wide and installed a network of galvanized wire mesh length of $16 \mathrm{~mm}$ square to allow the fall of pulp pills only through it (Fig. 5). It's installed on the frame of the two sides until they crank reciprocating movement to chapter sieve and the upper sides to complete the reciprocating movement .

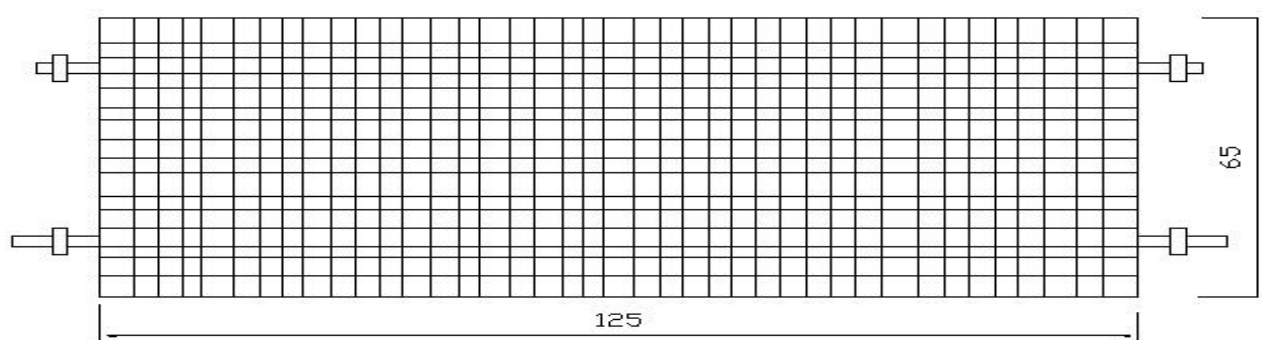

Fig.5. The seeds separation unit.

The seeds augers is collected the seeds and discharged in the collection tank. It is a column of spiral in one direction with length of $155 \mathrm{~cm}$ and diameter of $2.5 \mathrm{~cm}$.

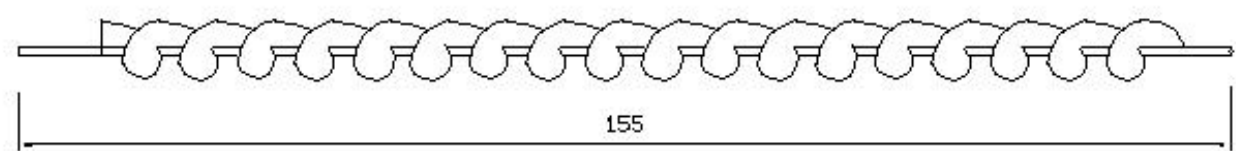

Fig.6. The seeds augers.

The main frame (chassis) is fabricated from $U$ shape iron with cross sectional area of $100 \times 50 \times 5 \mathrm{~mm}$. The min outer dimensions of the frame are $180 \mathrm{~cm}$ length, $120 \mathrm{~cm}$ width and $170 \mathrm{~cm}$ height. This frame includes elements to fix a hitching system, gear box, parts of power train, threshing unit, water melon conveyer unit, separating the melon seed unit, collecting the seeds and the in let tank. The prototype has four rubbers tire wheels of $50 \mathrm{~cm}$ diameter each. 
Gearbox is fixed on back of main frame to transmit rotary speed from tractor PTO by universal. This gearbox consisted of two conical gears 10 teeth each fixed on the two perpendicular shafts. When the universal joint is engaged between tractor PTO and gearbox shaft, the motion is confided.

The mean values of crop characteristics of watermelon Sakha 101 were plant height, $95 \mathrm{~cm}, \mathrm{No}=$ of pulp per square meter is 546 and the mass of 1000 grain is 110.0 gram.

The main physical and mechanical properties of watermelon pulp were measured to collect the required information's help to mechanical ruche and extraction of seeds from watermelon. A number of 100 watermelon pulp were randomly chosen from farm to determine these properties. The determined properties that measured according to standard methods ( Table 2 ).

Table 3. Main Characteristics of the tested watermelon pulp.

\begin{tabular}{|c|c|}
\hline Physical properties & Average $\pm \mathrm{Sd}$ \\
\hline Diameter, $\mathrm{mm}$ & $98.5 \pm 6.55$ \\
\hline Height, mm & $95.8 \pm 12.3$ \\
\hline \multicolumn{2}{|l|}{ Watermelon seed: } \\
\hline -Length, mm & $15.5 \pm 0.35$ \\
\hline -Width, mm & $9.4 \pm 0.07$ \\
\hline -Thickness, mm & $2.7 \pm 0.15$ \\
\hline Sphericity & $0.99 \pm 0.07$ \\
\hline - Mass of watermelon, $\mathrm{g} /$ fruit & $1030 \pm 225$ \\
\hline - Mass of seeds per watermelon, & $44.0 \pm 0.06$ \\
\hline Volume, $\mathrm{cm}^{3}$ & $1096 \pm 240.2$ \\
\hline Density, $\mathrm{g} / \mathrm{cm}^{3}$ & 0.939 \\
\hline No. of seeds/ watermelon & \pm 15.8 \\
\hline Bulb thickness, $\mathrm{cm}$ & $3.35 \pm 4.6$ \\
\hline No. of watermelon/fed. & 15600 \\
\hline
\end{tabular}

.Sd. Standard Deviation

The experiments were conducted on the prototype at four federating $(100,130,160$ and $200 \mathrm{~kg} / \mathrm{mine})$, four drum speed $(6.2,8.5,10.6$ and $13.2 \mathrm{~m} / \mathrm{se})$ and four resting days after harvest (2.0, 4.0, 6.0 and 8.0 days) on the following measurements. Seed losses $\%$, seed damaged $\%$, productivity machine $\mathrm{kg} / \mathrm{h}$, machine efficiency\%, consumed power kW and criterion cost L.E/h. 
The visible seed damaged, which have any damaged due to the using of extracting prototype estimated by following formula. Visible seed damage, $=\frac{\text { Mass of damaged seeds in sample, } g}{\text { Total mass of seeds in sample, } g} \times 100, \%$

The seeds that found mixed with peels for each treatment was manually clocked and weighted. Hence the percentages of seed losses were determined using the following relationship:

- Seed losses, $=\frac{M_{1}}{M_{1}+M_{2}} \times 100, \%$

where:

$M_{1}=$ Mass of total lost seed either with hull or discharged out of the prototype, $g$ and

$M_{2}=$ Mass of seeds from output opening, $g$

The cleaned seeds were collected from the seed opening and weighed $\left(M_{2}\right)$. Also, the seeds, which expelled with the peels and foreign matters were picked and weighed $\left(M_{c}\right)$.The cleaning efficiency was calculated according the following equation:

The cleaning efficiency $=\frac{M_{c}}{M_{c}+M_{2}} \times 100 \% 9$

The machine productivity M.P was determined

by the following equation:

M.P $=\frac{60 M t}{T e \times 1000}, \mathrm{~kg} / \mathrm{h}$,

(4)

Where:

$$
\begin{aligned}
& M_{t}=\text { mass of collected seeds, } g, \text { and } \\
& T_{e}=\text { machine running time. }
\end{aligned}
$$

To estimate the engine power during operation according the decrease in fuel level accurately measuring immediately after each treatment by fuel consumption device that is connected. The following formula was used to estimate the engine power (Hunt, 1983):

$$
E_{p}=\left(F_{c} \times \frac{1}{3600}\right) \rho_{F} \times \text { L.C.V. } \times 427 \times \eta_{\text {th }} \times \eta_{m} \times \frac{1}{75} \times \frac{1}{1.36}, K w-
$$

Where:

$$
\mathbf{}_{\mathbf{p}} \quad=\text { Power required, } \mathrm{Kw}
$$


$\boldsymbol{c}_{\mathbf{c}} \quad=$ the fuel consumption, $\mathrm{L} / \mathrm{h}$
$\mathrm{C}_{\mathrm{F}} \quad=$ the density of fuel, $0.85 \mathrm{~kg} / \mathrm{l}$

L.C.V = the lower calorific value of fuel, $11000 \mathrm{k} \mathrm{cal} / \mathrm{kg}$,

$427=$ thermo - mechanical equivalent, $\mathrm{kg} \cdot \mathrm{m} / \mathrm{k}$.cal.

$\eta_{\text {th }}=$ the thermal efficiency of engine, $35 \%$ for diesel engine, and

$\eta_{\mathbf{m}}=$ the mechanical efficiency of engine, $80 \%$ for diesel engine.

Cost estimated according to Hunt, (1983) as follows:

Total cost $(\mathrm{LE} / \mathrm{h})=$ Fixed cost $(\mathrm{LE} / \mathrm{h})+$ Variable $\operatorname{cost}(\mathrm{LE} / \mathrm{h})$

Unit costs (UC): The unit costs, (LE/ton) was estimated as follows:-

Unitl cost $=\frac{\text { Total cost LE/h }}{\text { Eouipment capacity }}, L E / h$

(7)

The criterion cost was estimated according to the following equation

$\mathrm{C}_{\mathrm{r}}=\mathrm{U}_{\mathrm{c}}+\mathrm{L}_{\mathrm{c}}+$ Vis $_{\mathrm{c}}$

where:

$$
\begin{aligned}
& \mathrm{C}_{\mathrm{r}}=\text { the criterion cost, } \mathrm{LE} / \mathrm{fed}, \\
& \mathrm{U}_{\mathrm{c}}=\text { unit cost, } \mathrm{LE} / \text { ton, } \\
& \mathrm{L}_{\mathrm{c}}=\text { losses cost, LE/ton, and } \\
& \mathrm{Vis}_{\mathrm{c}}=\text { visible damage cost, LE/ton. }
\end{aligned}
$$

\section{RESULTS AND DISCUSSIONS}

\section{Seed losses, \%}

The observations indicated in Fig.7 show the effect of number of resting days after harvesting on seed losses at different feeding rate and drum speeds. The data reveal that the percentage of seed losses decreases by increasing the number of resting days after harvesting from 2 to 6 days and the percentage of seed losses became increase by increasing the number of resting days after harvesting from that. This is due to increase adhesion to the internal content of seeds watermelon pulp. However, increasing drum speed from 6.2 to $13.2 \mathrm{~m} / \mathrm{s}$ tends to decrease the percentage of seed losses from 4.9 to $3.6 \%$ at feeding rate of $100 \mathrm{~kg} / \mathrm{min}$ and 7.0 to $5.4 \%$ at feeding rate of $200 \mathrm{~kg} / \mathrm{min}$ respectively. It was less than the percentage of seed losses with increasing drum speed and increased feed rates. The highest seed losses of $7.0 \%$ was obtained at number of resting days after harvest of 2 days, drum speed of $6.2 \mathrm{~m} / \mathrm{s}$ and feeding rates of $200 \mathrm{~kg} / \mathrm{min}$. 


\section{Seed damaged, \%}

Data illustrated in Fig.8.Shows the effect of number of resting days after harvest on seed damaged at different feed rate and drum speeds. The data reveal that the percentage of seed damaged decreases by increasing the number of resting days after watermelon harvesting from 2 to 8 days at all feeding rates. Also it is clear that, increase the drum speed from 6.2 to $13.2 \mathrm{~m} / \mathrm{s}$ tends to increase the percentage of seed damaged from 1.6 to $1.75 \%$ at 2 days after harvesting and feeding rate of $100 \mathrm{~kg} / \mathrm{min}$. The seed damaged decreases by increasing feed rates. This is due to the dense layers of material passing between drum and concave bars at high feed rates which provide more protection and reducing the repeated impacts by the drum bars. The highest seed damaged of $1.75 \%$ was obtained at number of resting days after harvest of 2 days, drum speed of $13.2 \mathrm{~m} / \mathrm{s}$ and feed rates of $100 \mathrm{~kg} / \mathrm{min}$.

\section{Productivity, kg/h.}

The observations indicated in Fig.9 shows the effect of number of resting days after harvest on productivity at different feeding rate and drum speeds. It is clear that, increasing the number of days after harvesting from 2 to 6 days, drum speed from 6.2 to $13.2 \mathrm{~m} / \mathrm{s}$ and feed rates from 100 to $200 \mathrm{~kg} / \mathrm{min}$ tends to increase the productivity. By increasing the number of resting days from 6 to 8 days tends to decrease the productivity because the length of this time after harvest grain become more attached to the existing grease around leads to increase the percentage of grain losses. For example, increasing feed rates from 100 to $200 \mathrm{~kg} / \mathrm{min}$ tends to increase the productivity from 289.2 to $567.6 \mathrm{~kg} / \mathrm{h}$ at drum speed of $13.2 \mathrm{~m} / \mathrm{s}$ and number of resting days of 2 days. The highest productivity of $579.0 \mathrm{~kg} / \mathrm{h}$ was recorded at feed rates of $200 \mathrm{~kg} / \mathrm{min}$, drum speed $13.2 \mathrm{~m} / \mathrm{s}$ and 6 days after harvest.

\section{Machine efficiency, \%}

Data illustrated in Fig.10. shows the effect of number of resting days after harvest dwell time on machine efficiency at different feeding rate and drum speeds. It was found that as the feeding rates increased as $100,130,160$ and $200 \mathrm{~kg} / \mathrm{min}$ the prototype efficiency decreased from $97.01,96.55,95.59$ and $94.65 \%$ was obtained at drum speed of $6.2 \mathrm{~m} / \mathrm{s}$ and 6 days after harvest. While increasing drum speed from 6.2 to $13.2 \mathrm{~m} / \mathrm{s}$ tends to increased the prototype efficiency from 93.5 to $94.65 \%$ at feeding rates $100 \mathrm{~kg} / \mathrm{min}$ and 2 days after harvest. The maximum prototype efficiency of $98.15, \%$ was recorded at feeding rates of $100 \mathrm{~kg} / \mathrm{min}$, drum speed of $13.2 \mathrm{~m} / \mathrm{s}$ and 6 days after harvest. While the minimum prototype efficiency of $91.55, \%$ was recorded at feeding rates of $200 \mathrm{~kg} / \mathrm{min}$, drum speed of $6.2 \mathrm{~m} / \mathrm{s}$ and 2 days after harvest. 


\section{Power consumed, kW,}

The presented data in Fig.11 show the effect of number of resting days after harvest on power consumed at different feeding rate and drum speeds. It is clear that, increasing feeding rates and drum speed tends to increase the power consumed. However, increasing number of resting days after harvest tends to decrease the power consumed. It was found that as the drum speed increased from 6.2 to 13.2 $\mathrm{m} / \mathrm{s}$ tend to increase the total power consumed from 12.6 to $14.9 \mathrm{~kW}$, at feeding rates $100 \mathrm{~kg} / \mathrm{min}$ and 2 days after harvest. The highest value of the power consumed of $22.6 \mathrm{~kW}$, at feeding rates of $200 \mathrm{~kg} / \mathrm{min}$, drum speed of $13.2 \mathrm{~m} / \mathrm{s}$ and 2 days after harvest.

\section{Operating cost, L.E./fed.}

Data illustrated in Fig.12. Shows the effect of resting days after harvest on operating cost at different feeding rate and drum speeds. It was found that as the feeding rates increased as $100,130,160$ and $200 \mathrm{~kg} / \mathrm{min}$ the operating cost increased from 256.8, 304.8, 423.0 and 602.6 L.E./fed., was obtained at drum speed of $6.2 \mathrm{~m} / \mathrm{s}$ and 6 days after harvest. While increasing drum speed from 6.2 to $13.2 \mathrm{~m} / \mathrm{se}$ tends to decreased the operating cost from 389.8 to 317.6 L.E./fed., at feeding rates 100 $\mathrm{kg} / \mathrm{min}$ and 2 days after harvest. The maximum operating cost of 819.9 L.E./fed., was recorded at feeding rates of $200 \mathrm{~kg} / \mathrm{min}$, drum speed of $6.2 \mathrm{~m} / \mathrm{s}$ and 2 days after harvest. While the minimum operating cost of 185.0 L.E./fed., was recorded at feeding rates of $100 \mathrm{~kg} / \mathrm{min}$, drum speed of $13.2 \mathrm{~m} / \mathrm{s}$ and 6 days after harvest.

\section{CONCLUSIONS}

The process of seeds separating from watermelon pulp mechanically considered one of the most important agricultural operations.

The main conclusions summarized as follows:

1- The highest seed losses of $7.0 \%$ was obtained at 2 days after harvest, drum speed of $6.2 \mathrm{~m} / \mathrm{s}$ and feeding rates of $200 \mathrm{~kg} / \mathrm{min}$ and the highest seed damaged of $1.75 \%$ was obtained at 2 days after harvest, drum speed of $13.2 \mathrm{~m} / \mathrm{s}$ and feed rates of 100 $\mathrm{kg} / \mathrm{min}$.

2- The highest productivity of $579.0 \mathrm{~kg} / \mathrm{h}$ was recorded at feeding rates of 200 $\mathrm{kg} / \mathrm{min}$, drum speed of $13.2 \mathrm{~m} / \mathrm{s}$ and 6 days of days after harvest.

3- The minimum prototype efficiency of $91.55, \%$ was recorded at feeding rates of $200 \mathrm{~kg} / \mathrm{min}$, drum speed of $6.2 \mathrm{~m} / \mathrm{s}$ and 2 days after harvest. The highest value of the power consumed of $22.6 \mathrm{~kW}$, at feeding rates of $200 \mathrm{~kg} / \mathrm{min}$, drum speed of $13.2 \mathrm{~m} / \mathrm{s}$ and 2 days after harvest. The minimum operating cost of 185.0 L.E./fed., was recorded at feeding rates of $100 \mathrm{~kg} / \mathrm{min}$, drum speed of $13.2 \mathrm{~m} / \mathrm{s}$ and 6 days after harvest. 
Drum speed, $\mathrm{m} / \mathrm{se} . \quad-\mathbf{\Delta}-6.2 \quad-\boldsymbol{-}-8.5-\bullet-10.6 \quad-\mathrm{x}-13.2$
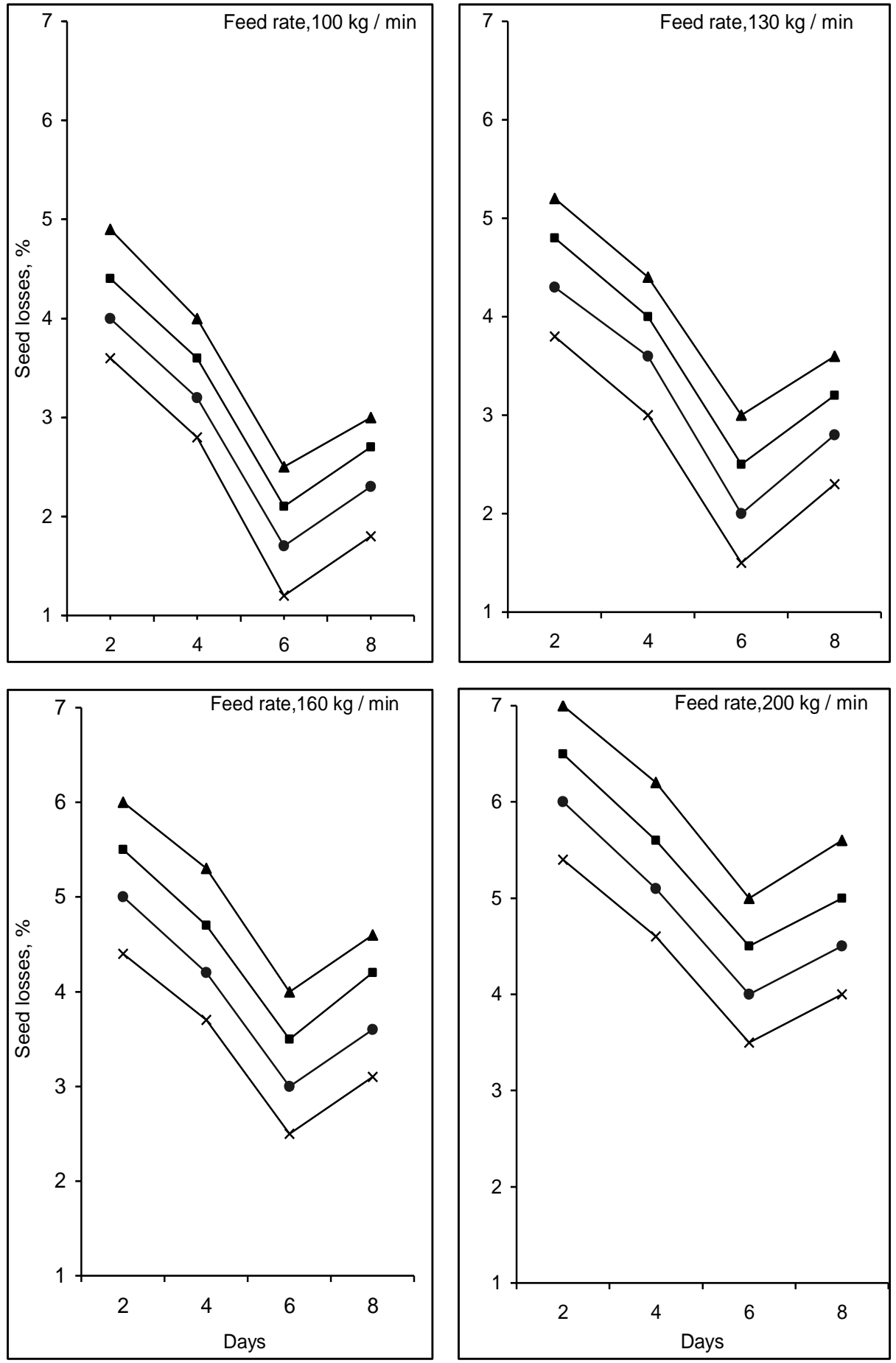

Fig. 7. Effect of number of resting days after harvesting on seed losses at different feeding rate and drum speeds. 
$-6.2$

$8.5-\bullet-10.6-x-13.2$
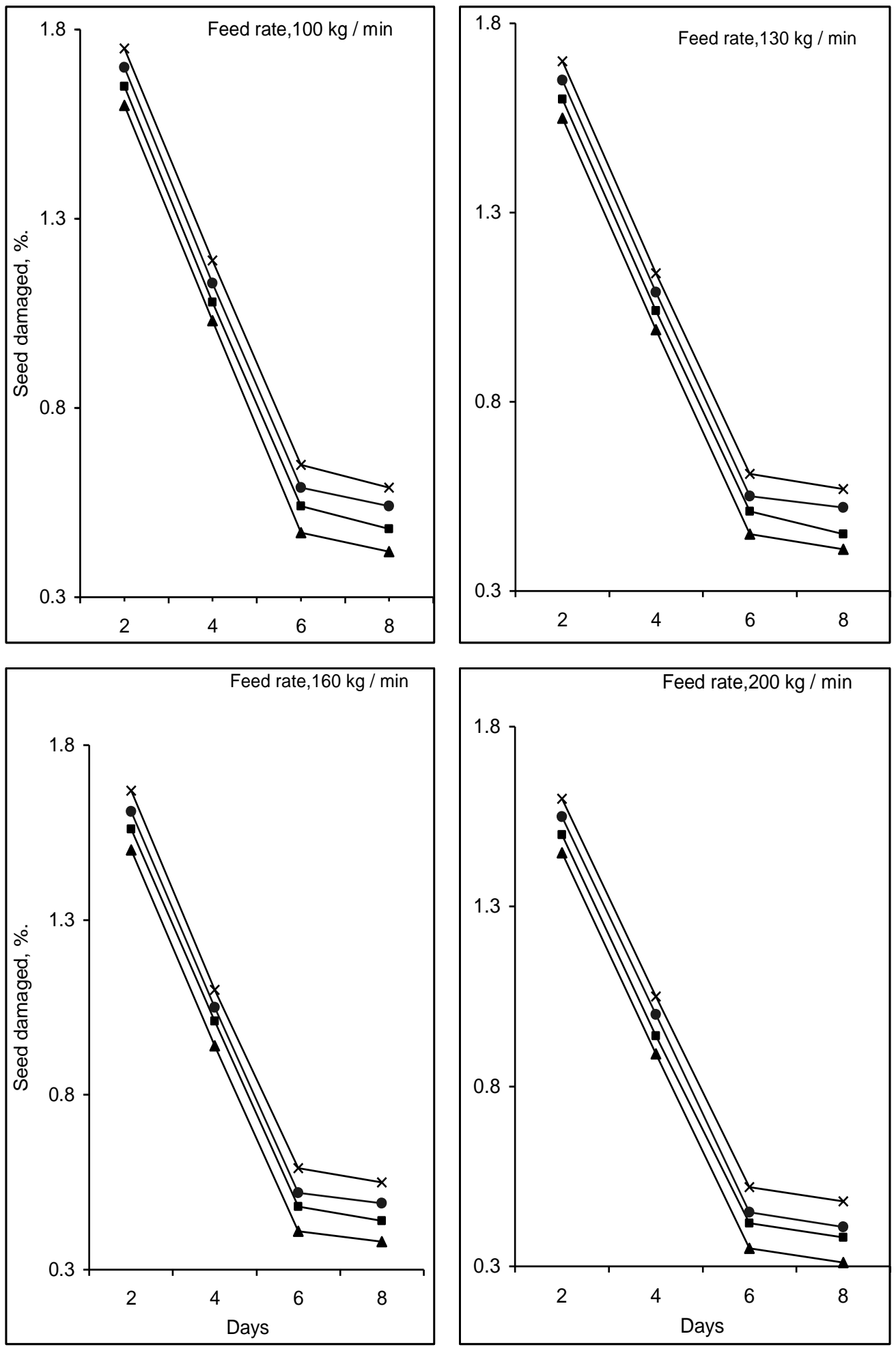

Fig. 8. Effect of number of resting days after harvesting on seed damaged at different feeding rate and drum speeds. 


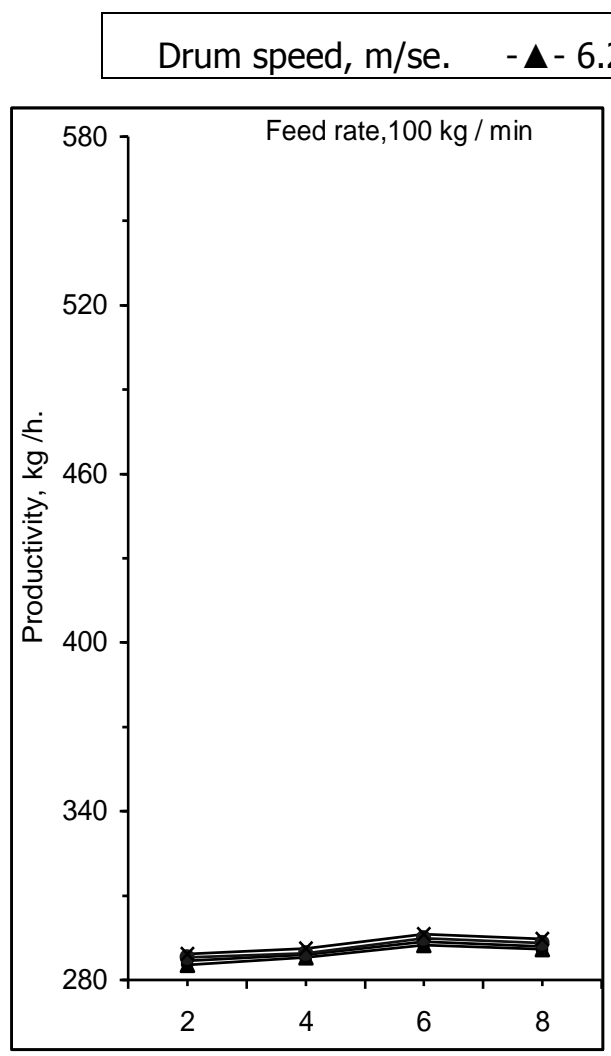

$-\square-8.5-\bullet-10.6-x-13.2$
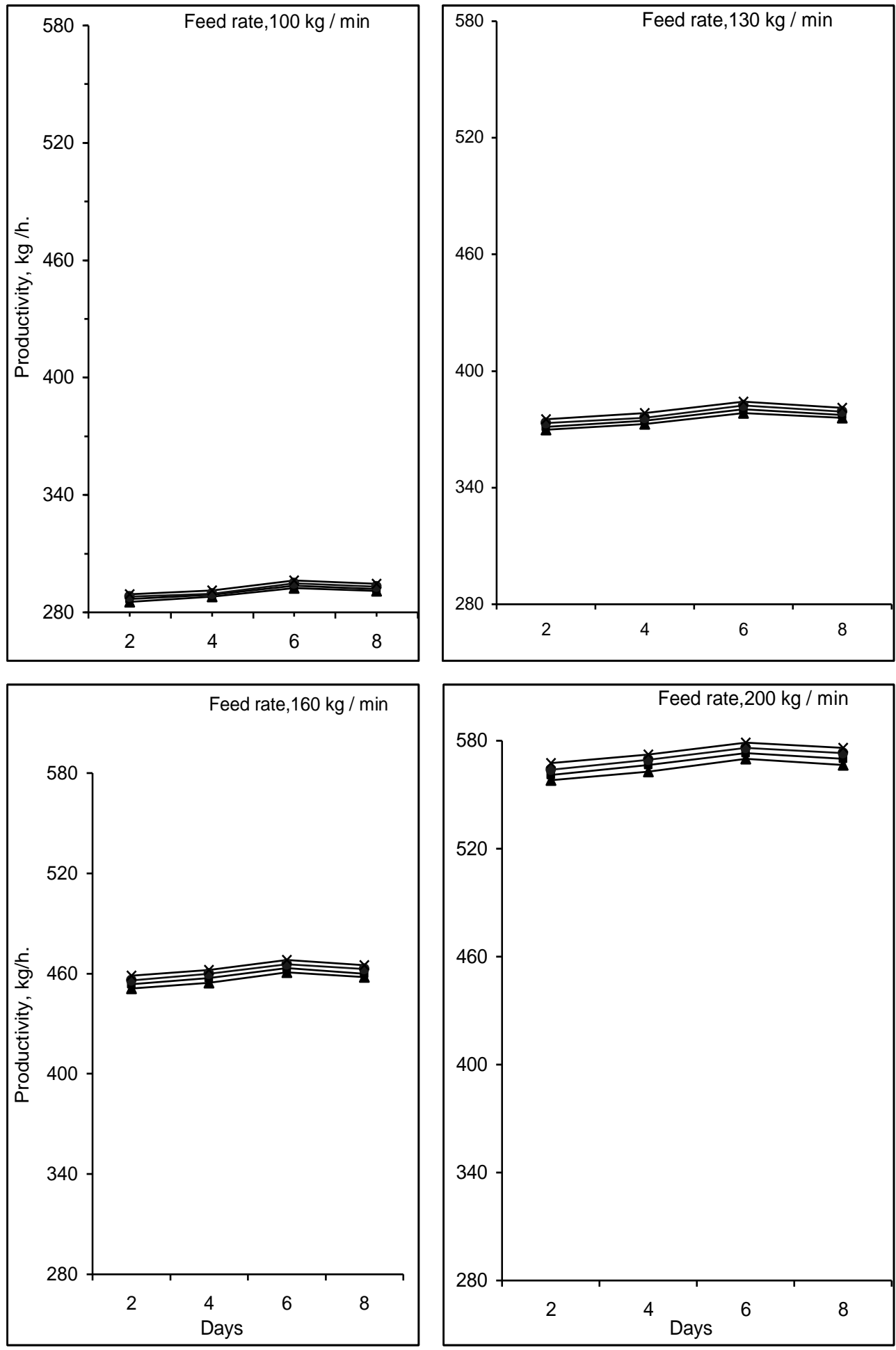

Fig. 9. Effect of number of resting days after harvesting on productivity at different feeding rate and drum speeds. 
Drum speed, $\mathrm{m} / \mathrm{se}$.

$\Delta-6.2$

$-8.5-\bullet-10.6-x-13.2$
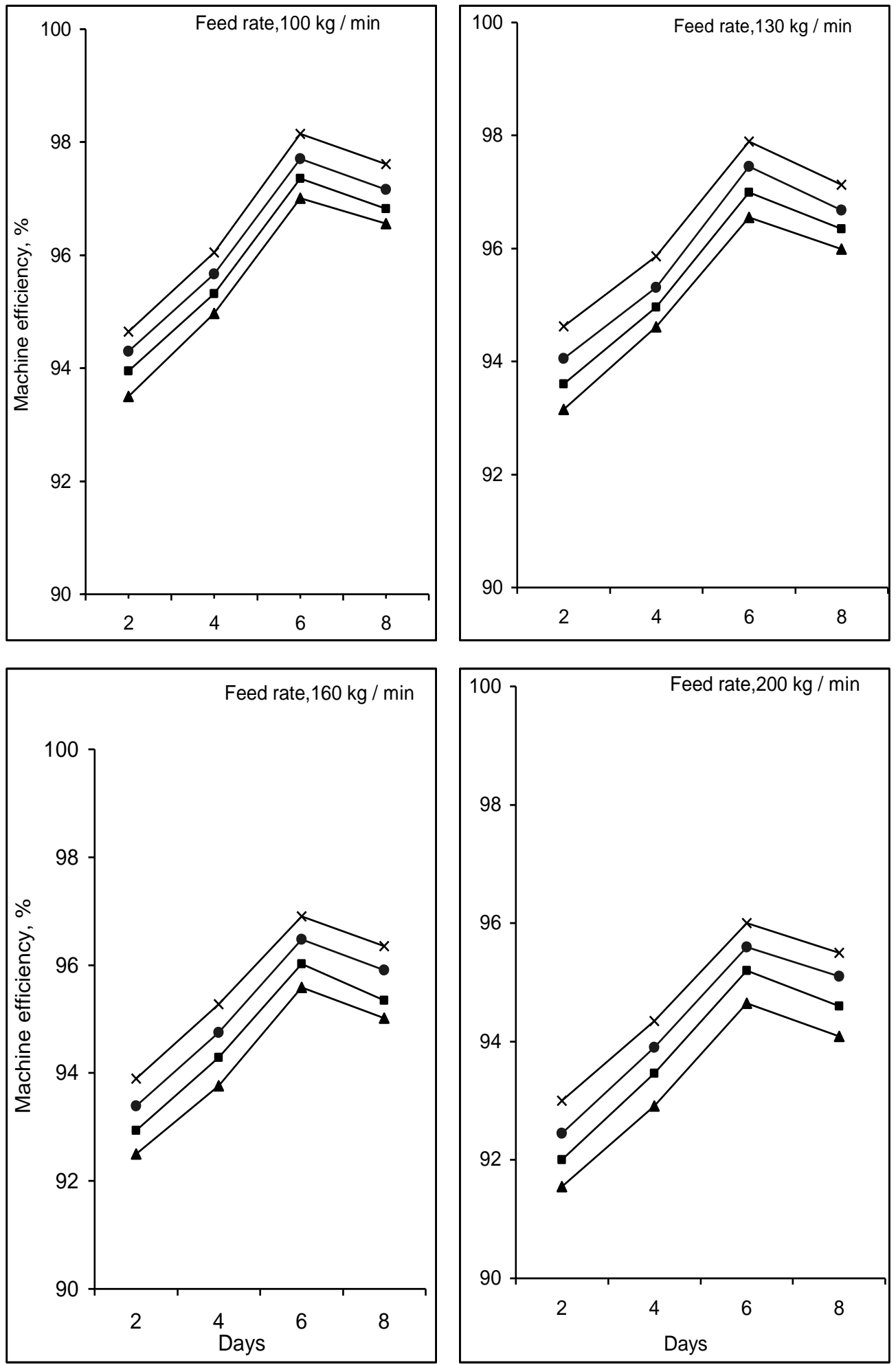

Fig. 10. Effect of number of resting days after harvesting on machine efficiency at different feeding rate and drum speed. 


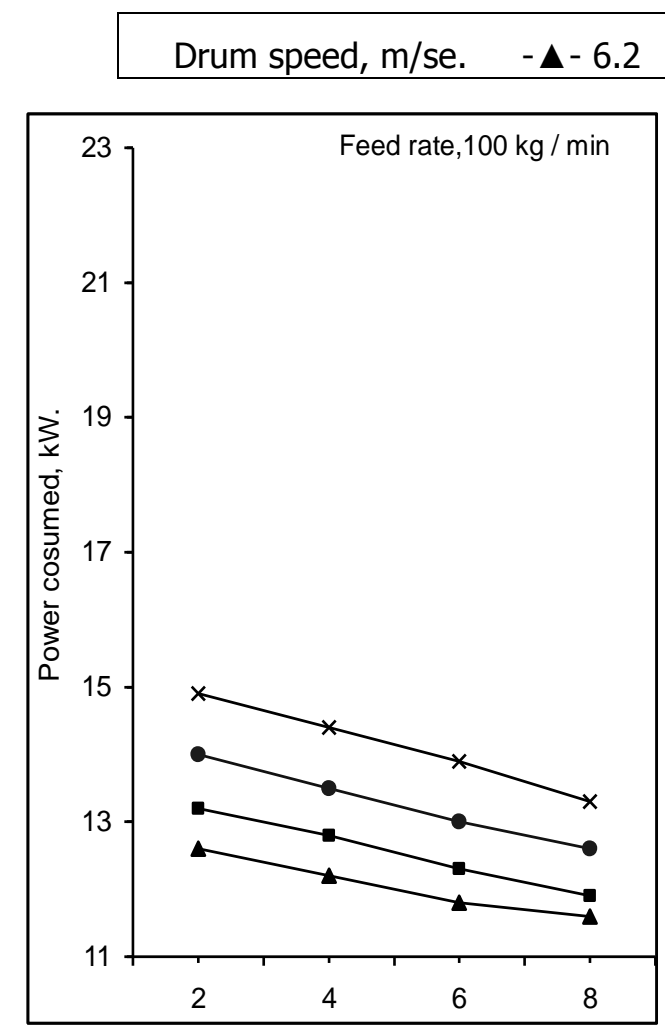

\section{$8.5-\bullet-10.6-x-13.2$}
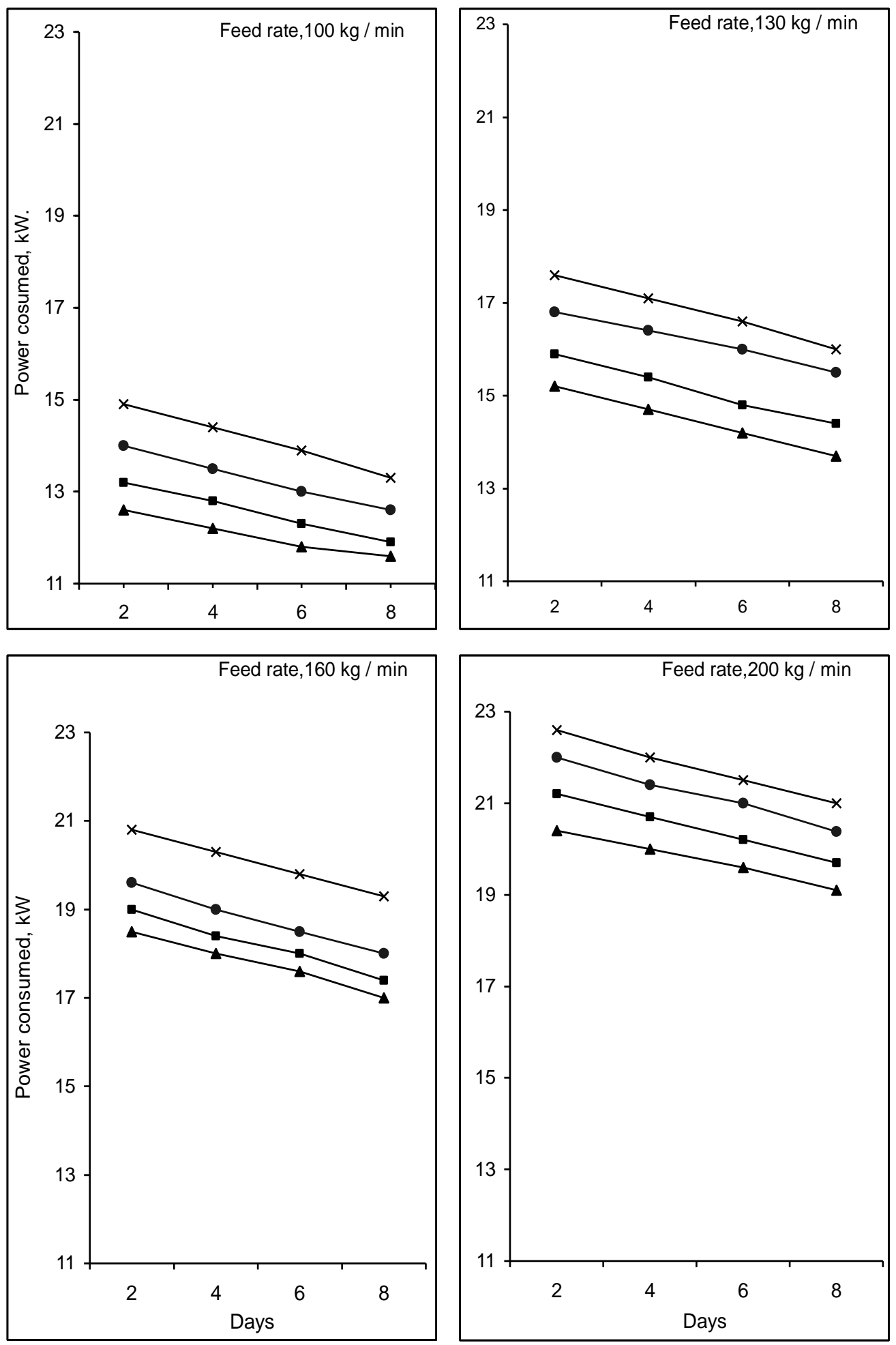

Fig. 11. Effect of number of resting days after harvesting on power consumed at different feeding rate and drum speed. 
Drum speed, m/se.

$-6.2$

$8.5-\bullet-10.6-x-13.2$
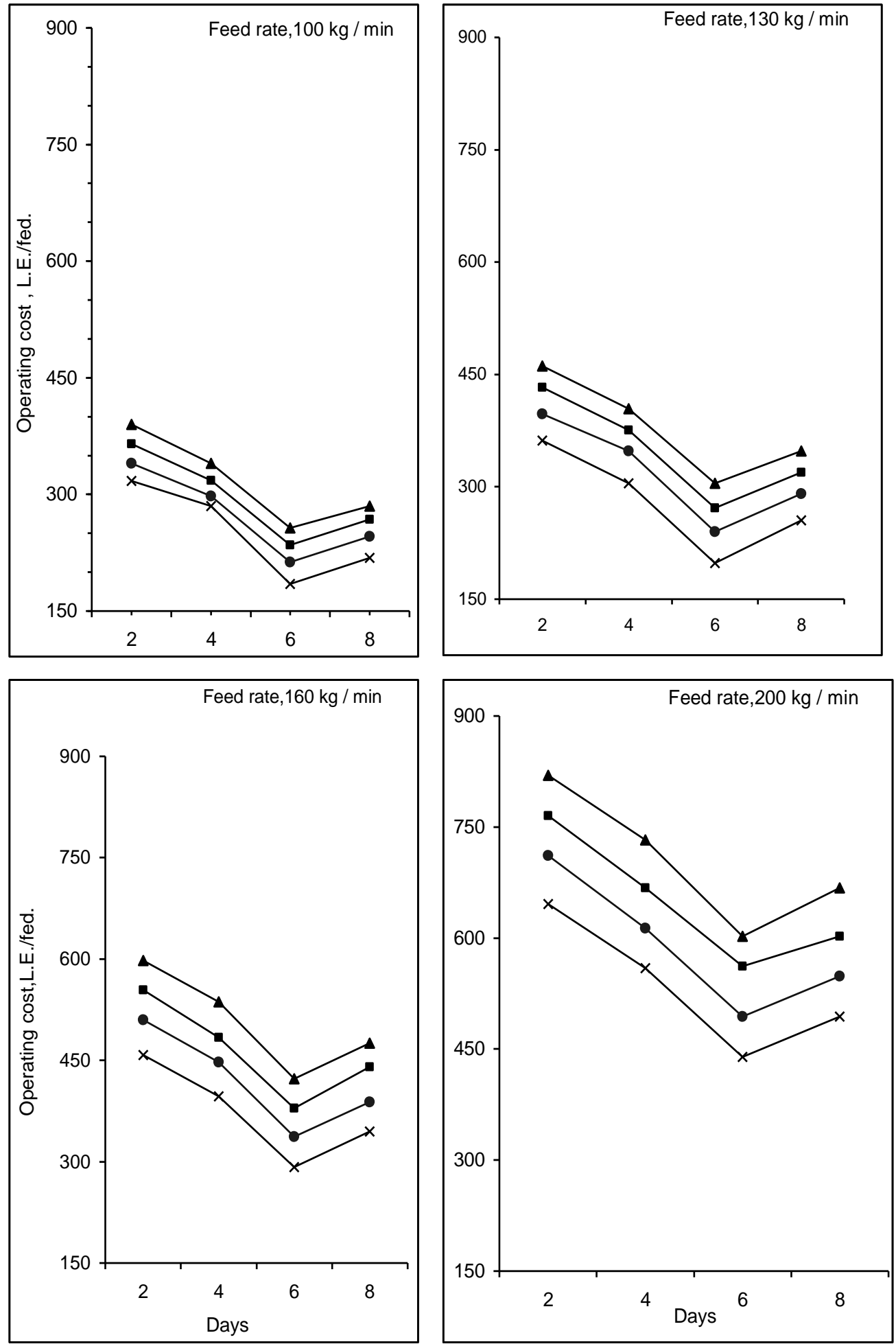

Fig. 12. Effect of number of resting days after harvesting on operating cost at different feeding rate and drum speed. 


\section{REFERENCES}

1. Abd EL-Hameed, E.M.A., 1994. Studying concave drum factors and operation locally manufactured thresher and their effect on thresher and their effect on threshing efficiency. M. Sc. Thesis, Agric. Eng. Dept., Fac. of Agric.,AinShamesUniversity.

2. Abou-Elmagd, A.E., A.S. Hamam, M.A. EL-Saadany and S.A. El-Kawaga ., 2002, "Design of a cone-end detacher for orange picking" Misr. J. Ag. Eng. 19(2): 491-507.

3. Abou-Elmagd, A.E., Abd El-Mageed, H.N., Baiomey, M.A., and Sayed-Ahmed, I.F. 2006. proper design and evaluation of an equipment for extracting watermelon seeds, J.Agric Sci. Mansoura Univ., 31(7) : 53-68.

4. Baldwin, J.A., 1990. Peanut, a grower's guide to quality. J. publ. by Planters L Savers Co., Winston-Salem, North Carolina, US.

5. El Lithy, A.M. 2012. Studying physical and mechanical properties of cantaloupe "charentais"fruits applied to design seed-extractor. Misr. J. Ag. Eng. 29(3): 11491161.

6. Hunt, D. 1983. Farm power and machinery management . $8^{\text {th }}$ Ed. Lowa state Univ., Press Ames, USA. Ames, Lowa, USA: 364-368.

7. Kolief R. M, R. R. Abo-Shieshaa and A. El-Mesery. 2005, Development and evaluation of seed extracting machine for seed melons. Misr. J. Ag. Eng, 22(2) : 555-571

8. Ministry of Agriculture, 2012. Agricultural statistics, Economic Issues sector, Cairo, Egypt: 78-115.

9. Tayel.S.A., EL-Nakib A. A., Khairy. M.F.A, Kamel, O.M and Desouky D. M. 2010. Factors affecting cucurbita-pepo crop seed losses and damage by using a seed extracting machine prototype. Misr. J. Ag. Eng, 27(3) : 824-837

10. Vergano, P.J., Testion, R.F., Choudhari, A.C.and Newall, W.C. 1992. peach vibration bruising: The effect of paper and plastic films between peaches, J.of Food Quality 15(3) : 183-197.

11. Yehia, I., Arif.E. M., El Lithy, A. M., Attallah. M. 2010. physical and mechanica properties of cantaloupe applied to design seed-extraction machine Misr J.Ag.Eng.,35(2)1036-1053. 


\section{تصنيع نموذج أولى لفصل بذور بطيخ اللب}

\section{عادل فتحي عبده عبد ربة}

قسم بحوث نظم ميكنة العطليات الزراعية - معهة بحوث الهندسة الزراعية - الدقي - الجيزة - مصر.

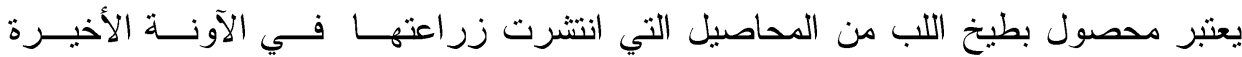

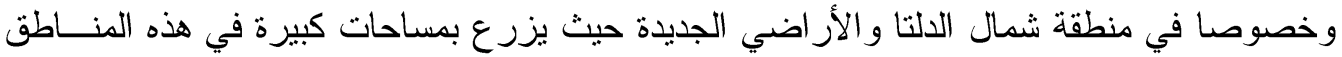

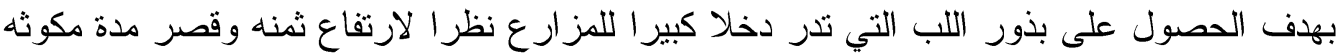

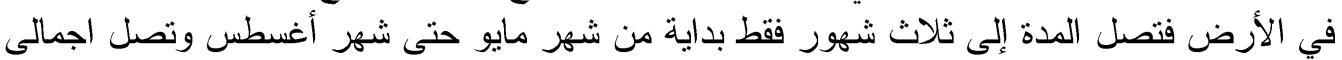

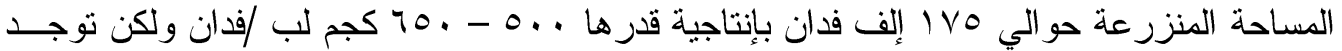

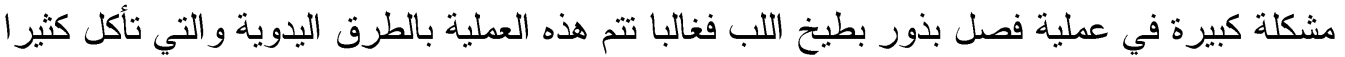

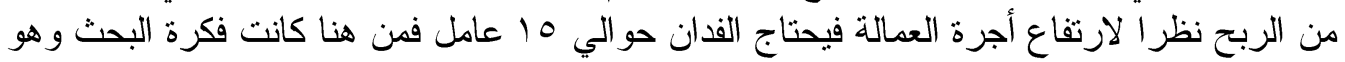

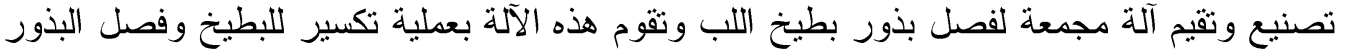

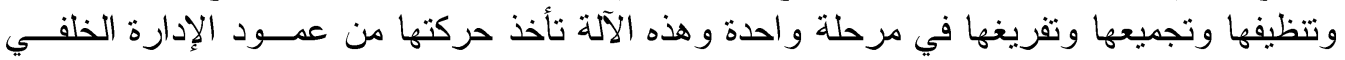
للجر ار وهى مقطورة خلفه وقد روعي في تصنيع هذه الآلة الأهداف الآتية:

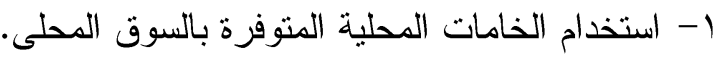

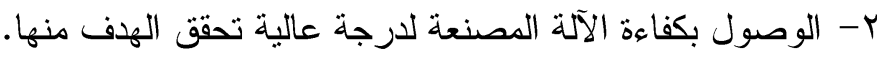
ب- سهولة الفك و التركيب لأجز ائها.

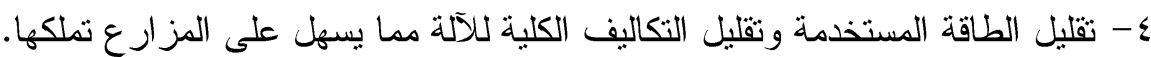

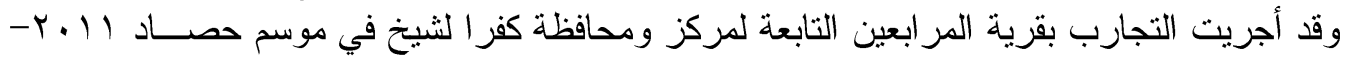

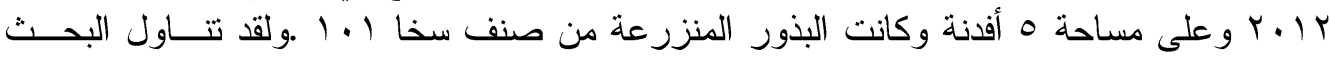

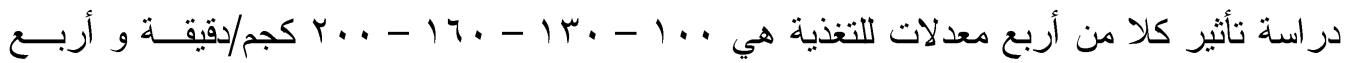

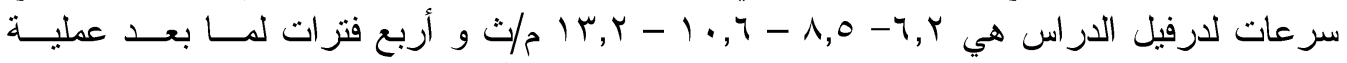

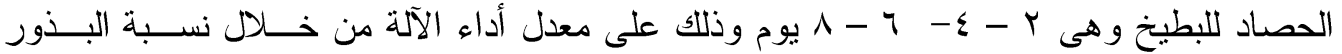

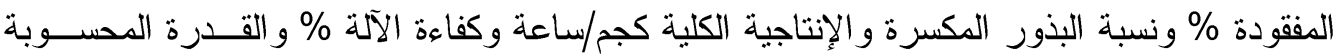

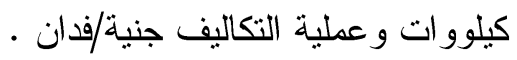
من أهم النتائج التي تم التوصل التول إليها

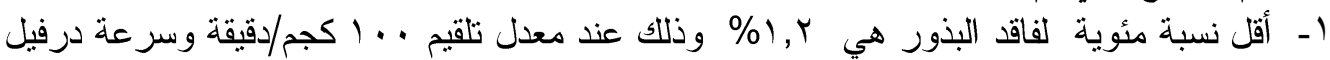

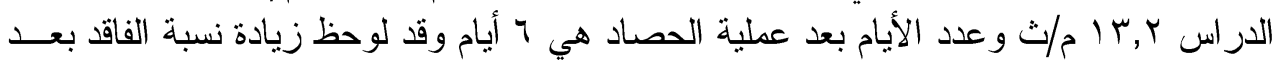

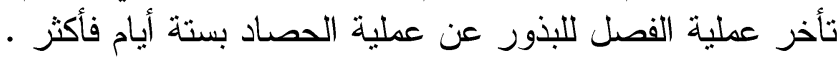

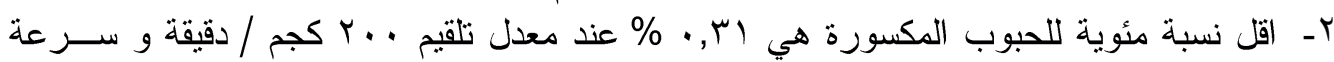

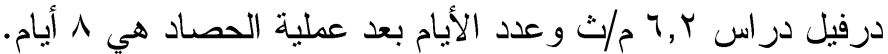

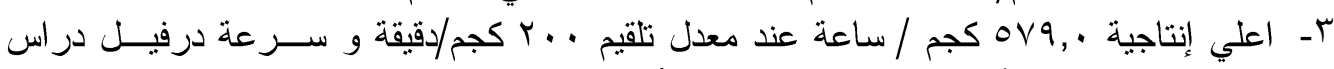

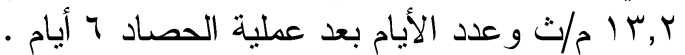

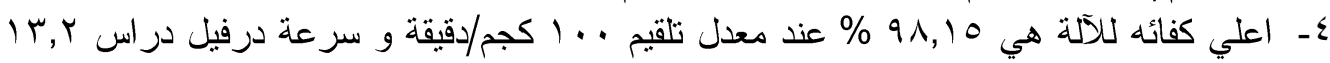

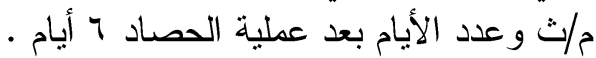

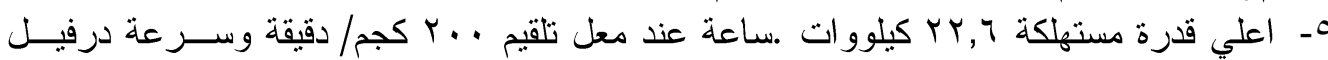

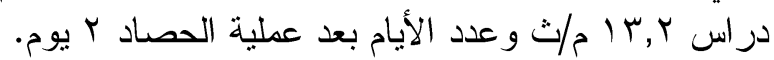

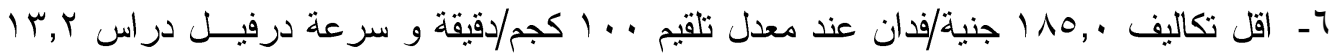
م/ث و عدد الأيام بعد عملية الحصاد 7 أيام . 